\title{
Growth and phenology variation in progeny of Scots pine seed orchards and commercial seed stands
}

\author{
Daniel J. Chmura $\cdot$ Roman Rożkowski • \\ Władysław Chałupka
}

Received: 8 July 2011/Revised: 1 December 2011 / Accepted: 24 January 2012/Published online: 9 February 2012

(C) The Author(s) 2012. This article is published with open access at Springerlink.com

\begin{abstract}
Tree improvement in Poland has been most advanced for Scots pine, but existing seed orchards have not been progeny-tested yet. We examined variation in growth traits-tree height at ages 4 and 8 years, and diameter at age 13 years-in the common garden experiment testing open-pollinated progenies of 31 seed orchards and 5 commercial seed stands (referred to as populations) at 5 locations. We also examined bud burst phenology at two to five sites at three growing seasons. At one experimental site during the 5th growing season, we measured shoot growth rhythm on all populations. Similar measurements of shoot growth were done on a subset of populations during the 6th growing season together with the analysis of needle growth and foliar chemistry. We found significant variation among populations in growth traits, but also significant population $\times$ site $(G \times E)$ interactions. We used the regression approach and ecovalence analysis to examine populations' performance stability. Most populations had average responsiveness to environment, and a set of least-responsive poor-growing populations contributed the most to the $\mathrm{G} \times \mathrm{E}$ interaction. Variation in bud burst phenology was associated with geographical distribution of tested progenies. The early bud-bursting populations originated from the north-eastern to north-central
\end{abstract}

Communicated by U. Berger.

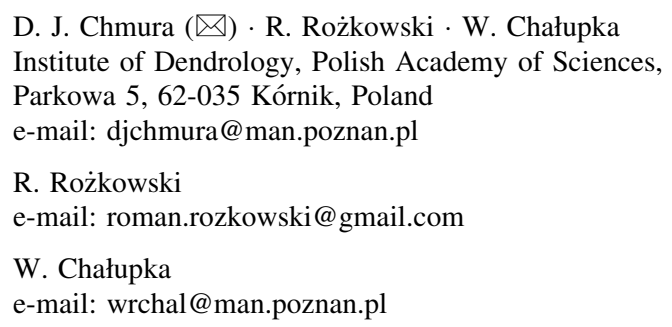

Poland, and a group of late bud-bursting populations originated mainly from the south-eastern region. Correlations between bud burst and growth traits were weak to medium and varied by site, but early bud-bursting populations tended to show stronger growth on height and diameter. We found significant differences among populations in final leader length, shoot elongation time and relative growth rate (RGR). However, RGR and shoot elongation time explained less than $30 \%$ of variation in leader length and were weakly correlated with tree height. Populations varied in needle length, specific leaf area and foliar nitrogen concentration, but time trends in these traits did not vary among populations or predefined groups of populations. Therefore, the analysis of growth rhythm or needle traits did not help resolve variation in tree growth to support selection decisions. Contrary to our expectation, progeny of seed orchards did not perform significantly better than that of commercial seed stands. This finding, however, should not be extrapolated beyond our set of populations. Nonetheless, the local seed sources were not always the best. From a selection standpoint, our results help culling the worst populations rather than selecting the best ones. Therefore, testing individual family progeny and genetic roguing of existing seed orchards is highly recommended.

Keywords Bud burst - Ecovalence .

Genotype $\times$ environment interaction - Growth rhythm .

Pinus sylvestris · Stability

\section{Introduction}

Organized large-scale tree improvement programs have over 60-year-long history (Zobel and Talbert 1984), but 
tree breeding is still in the early stages compared to advances in agriculture and horticulture. Tree improvement is based on selection, progeny-testing and breeding of selected material to increase productivity, improve quality or enhance resistance to pests and stresses. For example, it is estimated that volume production is between 10 and $30 \%$ higher when using improved versus unimproved planting material in pines (McKeand et al. 2003; Mikola 1991), but these estimates will vary by species, selection intensity and geographic region.

Breeding is traditionally conducted in seed orchards that are established with vegetatively propagated trees. Firstgeneration seed orchards typically involve clones of trees that are selected based on superiority of their phenotype (plus trees). As information on genetic quality (breeding value) of selected parent trees becomes available, it is used for roguing the existing and establishing new next-generations seed orchards. Production of seeds in seed orchards allows to realize genetic gain from selection and to reduce cost of seed procurement. It also makes possible to use flower stimulation techniques for increasing seed production (Bonnet-Masimbert and Webber 1995; Chałupka 1991). However, all operations have to be designed so that to secure cost-efficiency of a tree improvement program.

Tree improvement in Poland has been historically focused at a population level (Giertych 1999). Among the major forest tree species, selection efforts are most advanced for Scots pine (Pinus sylvestris L.). Nevertheless, most of reforestation in Poland is attained with seeds produced either in commercial seed stands (cut at the time of good seed crop) or registered (permanent) seed stands. Seed orchard seeds have not been used adequately so far compared to their potential range of application. However, the existing Scots pine seed orchards have not been progeny-tested yet, and their genetic quality is generally unknown. Thus, it is necessary to assess performance of seed orchards' progeny, especially in comparison with the progeny of commercial seed stands.

Selection decisions are often complicated by the existence of genotype $\times$ environment $(\mathrm{G} \times \mathrm{E})$ interaction (reviewed in Morgenstern, 1982). If $\mathrm{G} \times \mathrm{E}$ is considerable, it may be advisable to group target environments into homogenous zones where each zone requires its own set of selections suitable for planting (Matheson and Cotterill 1990). Thus, performance of genotypes involved in a tree improvement program should be estimated in a variety of possible planting environments.

In case of significant $\mathrm{G} \times \mathrm{E}$ interaction, additional stability measures are needed to assess genotype performance. Many methods have been developed for that purpose in the literature. Finlay and Wilkinson (1963) used the regression coefficient $\left(b_{i}\right)$ of individual population means plotted against site means as an estimate of stability. Eberhart and
Russell (1966) advocated the use of deviations from regression $\left(s_{d i}^{2}\right)$ as an additional measure of stability. In the review of available statistics for phenotypic stability, Becker and Léon (1988) argue that $b_{i}$ is not strictly a stability measure, but rather a response parameter reflecting the responsiveness of a genotype to environmental conditions. To allow thorough analysis of phenotypic stability, they propose other parametric and nonparametric statistics (Becker and Léon 1988). Information on ecovalence $\left(W_{i}\right)$ (Becker 1981; Wricke 1962) supported with the analysis of $b_{i}, s_{d i}^{2}$ and coefficient of determination $\left(R^{2}\right)$ from the regression approach was used for the analysis of $\mathrm{G} \times \mathrm{E}$ interaction in many studies with trees (e.g. Isik and Kleinschmit 2003; Owino 1977; Shutyaev and Giertych 2000). We adopted these methods in our study to assess stability of growth performance in tested progenies of Scots pine.

Populations of trees are in general adapted to their environments. Timing of bud burst is one of the adaptations allowing trees to avoid frost injuries to newly developing tissues from late spring frosts. If maladapted material is planted, repeated frost injuries may result in growth reductions and stem deformations. Genetic variations in bud burst timing have been found in large provenance experiments with Scots pine (Beuker 1994; Mátyás 1981; Steiner 1979a) and other coniferous tree species (Beuker 1994; Prescher 1982; Rehfeldt 1982; St. Clair et al. 2005; Steiner 1979a, b). This variability is often associated with climatic gradients within the species range. However, variation in bud burst can also be found at smaller geographic scales (e.g. Chmura 2006), reflecting adaptations to fine-scale environmental variability. We investigated differences in bud burst in our study to better characterize variation among progeny of Scots pine seed orchards.

Classical plant growth analysis has been used to understand contribution of morphological and physiological components underlying variation in plant growth and productivity (Evans 1998; Poorter 1989a). Relative growth rate (RGR) can be partitioned into its components-net assimilation rate (NAR, change in plant mass per unit leaf area per unit time) and leaf area ratio (LAR, leaf area per unit plant mass), and LAR can be further explained as a product of leaf mass ratio (LMR, proportion of leaf mass in total plant mass) and specific leaf area (SLA, leaf area per unit leaf mass) (Poorter and Garnier 1999; Poorter et al. 2009). Several techniques have been proposed in the literature for estimation of plant RGR (Hunt 1982; Poorter 1989b; Poorter and Garnier 1996). Strong correlations were found between RGR and LMR and especially SLA in a set of widely varying woody plant species (Cornelissen et al. 1998). Whereas analysis of NAR and LMR is laborious, the estimation of SLA is less time-consuming and could be easily included as a screening tool in tree improvement programs if strong enough association was found between 
SLA and tree growth. Because the interrelationships between SLA, leaf nitrogen concentration and carbon assimilation rates have been found in wide among-species comparisons (Reich et al. 1998a; Wright et al. 2004), and between assimilation rate and RGR (Reich et al. 1998b), it is of interest whether similar relationships exist within the species. In this study, we investigated variation in RGR, SLA and leaf nitrogen to determine whether the analysis of tree growth components would help explain growth differences between populations within the species.

This paper describes the results from the replicated common garden field experiment testing progenies of Scots pine seed orchards and commercial seed stands in Poland. The main purpose of this study was to examine (1) the extent of variability in growth performance and phenology among tested progenies; (2) the extent of $\mathrm{G} \times \mathrm{E}$ interaction and stability of tested progenies in examined traits; and (3) the relationship between spring growth phenology and growth performance. In addition, we were interested (4) whether growth rhythm analysis helps to explain causes of differences in growth among tested populations. From a commercial standpoint, we hypothesized that the progeny of seed orchards would perform better in terms of tree height and diameter than the progeny of commercial seed stands.

\section{Materials and methods}

Plant material and experimental sites

The study tests the performance of Scots pine clonal seed orchards progeny in Poland. The bulk samples of openpollinated seeds were collected in 1997 from 34 seed orchards in Poland, further referred to as populations (Table 1). The five progenies of commercial seed stands were also included in the experiment (Table 1; Chmura et al. 2003). These stands represent local populations to the planting sites according to the existing seed transfer rules in Poland (Załęski et al. 2000).

Because scions for seed orchard clones were collected according to the existing seed zonation in Poland, only seven seed orchards had unique sets of clones, and most populations in our study had at least some clones in common with other seed orchards. However, only two populations had their sets of clones completely overlapping with others-Sulechów 2 (17) had a subset of clones in Orneta (7) and Susz (19) seed orchards, and Leżajsk (33) had a subset of those in Sieniawa (31). The two latter populations also had some clones in common with seed orchards in Józefów (14) and Świdnik (25), creating a spatial group of genetically related populations. The Zaporowo (8) and Kwidzyn 1 (22) seed orchards shared much of their clonal sets. The four seed orchards in Runowo (10-13) also had some clones in common among themselves, and a few with Gniewkowo (2) and Kwidzyn 2 (23). In such circumstances, it is very likely that progenies of some seed orchards were related. However, because seeds were collected as bulk samples, it was impossible to estimate family structure and to account for genetic relatedness in our populations. Nevertheless, even if some seed orchards had some clones in common, the inclusion of unrelated clones and different clone assignments within the orchards have created a possibility of new allelic combinations. Thus, the tested progenies were analyzed as separate populations (fixed effect, see Statistical analysis below), but comparisons among presumably related populations were also explored in more detail.

The study consists of five experimental sites located in the State Forests enterprises: Wymiarki $\left(51^{\circ} 22^{\prime} \mathrm{N}, 14^{\circ} 59^{\prime} \mathrm{E}\right.$, $155 \mathrm{~m}$ a.s.1), Janów Lubelski $\left(50^{\circ} 37^{\prime} \mathrm{N}, 22^{\circ} 36^{\prime} \mathrm{E}, 210 \mathrm{~m}\right.$ a.s.1.), Choczewo $\left(54^{\circ} 39^{\prime} \mathrm{N} 17^{\circ} 58^{\prime} \mathrm{E}, 120 \mathrm{~m}\right.$ a.s.l. $)$, and Gołdap (54 $18^{\prime} \mathrm{N} 22^{\circ} 40^{\prime} \mathrm{E}, 220 \mathrm{~m}$ a.s.1.), and in the experimental forest "Zwierzyniec" of the Institute of Dendrology in Kórnik ( $52^{\circ} 14^{\prime} \mathrm{N}, 17^{\circ} 03^{\prime} \mathrm{E}, 80 \mathrm{~m}$ a.s.l.), Poland. The sites were established in spring 1999 in five completely randomized blocks with 39 plots per block at each site. Seedlots were randomly assigned to plots within blocks at each site. The 100 tree plots were planted in 5 rows of 20 seedlings in $1.5 \times 0.5 \mathrm{~m}$ spacing $(1.4 \times 0.5 \mathrm{~m}$ in Choczewo $)$. Because of insufficient number of seedlings, three populations were not represented at all as experimental sites; therefore, 36 populations common to all five planting sites were included in the analysis (Table 1). Detailed description of experimental sites is given in Chmura et al. (2003).

\section{Measurements}

The inventory data collected at all sites consist of measurements of tree height at age 8 years (2005), and diameter at $1.3 \mathrm{~m}(\mathrm{DBH})$ during the 13th growing season (2010). Tree height at age 4 years (2001) was reported in Chmura et al. (2003). First thinnings were done in 2005 (at age 8 years) in Janów Lubelski and Choczewo, and in 2010 (at age 13 years) in Kórnik. Therefore, survival was assessed only to the age of 8 years.

During the 5th growing season (2002), tree height growth rhythm was measured at the Kórnik site. The measurements started on March 20 (79th day of year) with the length of a dormant terminal bud and continued weekly until the end of shoot growth on July 10 (191 day of year). Measurements of growing shoots were taken with a ruler from a fixed point with a 1-mm accuracy. Seven to ten trees per population plot were measured in three blocks for the total of 1,070 trees. Total height of trees was measured after leader elongation was completed. 
Table 1 Means and standard errors (SE) of tree height at age 8 years and tree diameter (DBH) at age 13 years, and deviations from regression $\left(s_{d i}^{2}\right)$ and coefficients of determination $\left(R^{2}\right)$ for Scots pine populations tested at five planting sites

\begin{tabular}{|c|c|c|c|c|c|c|c|c|c|}
\hline \multirow[t]{2}{*}{ ID number } & \multirow[t]{2}{*}{ Population name } & \multicolumn{4}{|c|}{ Tree height at age 8 years } & \multicolumn{4}{|c|}{ Tree $\mathrm{DBH}$ at age 13 years } \\
\hline & & Mean $(\mathrm{cm})$ & SE & $s_{d i}^{2}$ & $R^{2}$ & Mean $(\mathrm{mm})$ & SE & $s_{d i}^{2}$ & $R^{2}$ \\
\hline 1 & Supraś1 ${ }^{1}$ & $243.15^{\mathrm{a}}$ & $(16.16)$ & 159.0 & 0.98 & $61.24^{\mathrm{ab}}$ & $(3.18)$ & 4.6 & 0.99 \\
\hline 2 & Gniewkowo $^{2}$ & $240.12^{\mathrm{ab}}$ & $(16.30)$ & 75.2 & 0.99 & $58.03^{\mathrm{abcd}}$ & $(2.72)$ & 5.6 & 0.98 \\
\hline 3 & Dwukoły & $234.04^{\mathrm{abc}}$ & $(14.85)$ & 17.2 & 1.00 & $58.57^{\mathrm{abcd}}$ & $(2.70)$ & 5.3 & 0.98 \\
\hline 4 & Międzylesie & $224.28^{\mathrm{abcd}}$ & $(15.47)$ & 54.3 & 0.99 & $58.67^{\mathrm{abcd}}$ & $(2.98)$ & 2.2 & 0.99 \\
\hline 5 & Gniezno & $240.91^{\mathrm{ab}}$ & $(14.59)$ & 50.2 & 0.99 & $58.70^{\mathrm{abcd}}$ & $(2.81)$ & 8.3 & 0.97 \\
\hline 6 & Skierniewice $^{1}$ & $224.97^{\mathrm{abcd}}$ & $(15.10)$ & 13.4 & 1.00 & $59.21^{\mathrm{abc}}$ & $(2.86)$ & 6.6 & 0.98 \\
\hline 7 & Orneta & $231.75^{\mathrm{abc}}$ & $(14.21)$ & 125.5 & 0.98 & $59.53^{\mathrm{abc}}$ & $(2.79)$ & 9.1 & 0.97 \\
\hline 8 & Zaporowo & $238.39^{\mathrm{ab}}$ & (15.99) & 49.6 & 0.99 & $57.84^{\mathrm{abcd}}$ & (3.04) & 2.3 & 0.99 \\
\hline 10 & Runowo 1 & $204.55^{\text {de }}$ & (13.95) & 152.2 & 0.98 & $53.75^{\mathrm{cd}}$ & (2.39) & 6.9 & 0.96 \\
\hline 11 & Runowo 2 & $227.75^{\text {abcd }}$ & $(14.21)$ & 177.1 & 0.98 & $57.77^{\mathrm{abcd}}$ & $(2.82)$ & 1.0 & 1.00 \\
\hline 12 & Runowo 3 & $228.59^{\mathrm{abcd}}$ & (15.96) & 74.3 & 0.99 & $58.62^{\mathrm{abcd}}$ & (2.98) & 1.4 & 1.00 \\
\hline 13 & Runowo 4 & $228.20^{\mathrm{abcd}}$ & (14.15) & 48.6 & 0.99 & $58.35^{\mathrm{abcd}}$ & $(2.59)$ & 2.6 & 0.99 \\
\hline 14 & Józefów & $211.95^{\mathrm{cd}}$ & (12.40) & 162.8 & 0.97 & $56.31^{\mathrm{abcd}}$ & $(2.25)$ & 0.3 & 1.00 \\
\hline 15 & Brzeg & $224.93^{\mathrm{abcd}}$ & $(15.41)$ & 34.7 & 1.00 & $59.38^{\mathrm{abc}}$ & $(2.80)$ & 0.9 & 1.00 \\
\hline 16 & Sulechów $1^{2}$ & $219.93^{\mathrm{abcd}}$ & (15.04) & 38.0 & 1.00 & $56.55^{\mathrm{abcd}}$ & $(2.76)$ & 0.6 & 1.00 \\
\hline 17 & Sulechów 2 & $227.95^{\mathrm{abcd}}$ & (14.03) & 22.6 & 1.00 & $55.82^{\mathrm{abcd}}$ & $(2.74)$ & 1.4 & 0.99 \\
\hline 18 & Bierzwnik $^{2}$ & $225.41^{\mathrm{abcd}}$ & $(13.42)$ & 133.5 & 0.98 & $57.04^{\mathrm{abcd}}$ & $(2.92)$ & 5.1 & 0.98 \\
\hline 19 & Susz & $234.45^{\mathrm{abc}}$ & (14.90) & 247.4 & 0.97 & $58.60^{\mathrm{abcd}}$ & $(3.04)$ & 4.9 & 0.98 \\
\hline 20 & Nowogard & $233.13^{\mathrm{abc}}$ & (15.22) & 60.3 & 0.99 & $59.02^{\mathrm{abcd}}$ & (3.12) & 10.6 & 0.97 \\
\hline 21 & Miechów $^{3}$ & $186.45^{\mathrm{e}}$ & (12.24) & 188.2 & 0.97 & $52.90^{\mathrm{d}}$ & $(2.21)$ & 10.8 & 0.94 \\
\hline 22 & Kwidzyn 1 & $225.21^{\mathrm{abcd}}$ & $(14.39)$ & 85.2 & 0.99 & $60.34^{\mathrm{ab}}$ & $(2.75)$ & 2.2 & 0.99 \\
\hline 23 & Kwidzyn 2 & $226.67^{\mathrm{abcd}}$ & $(14.92)$ & 193.1 & 0.98 & $57.98^{\mathrm{abcd}}$ & $(3.05)$ & 0.5 & 1.00 \\
\hline 24 & Zdrojowa Góra & $240.77^{\mathrm{ab}}$ & $(13.68)$ & 37.1 & 0.99 & $58.32^{\mathrm{abcd}}$ & $(2.95)$ & 0.3 & 1.00 \\
\hline 25 & Świdnik & $219.51^{\mathrm{abcd}}$ & (14.98) & 119.1 & 0.99 & $56.69^{\mathrm{abcd}}$ & $(2.40)$ & 4.6 & 0.98 \\
\hline 26 & Biała & $230.86^{\mathrm{abc}}$ & $(15.90)$ & 98.2 & 0.99 & $59.47^{\mathrm{abc}}$ & $(2.89)$ & 6.3 & 0.98 \\
\hline 27 & Oborniki Śl. & $228.00^{\mathrm{abcd}}$ & (14.80) & 16.2 & 1.00 & $57.44^{\mathrm{abcd}}$ & $(2.91)$ & 2.2 & 0.99 \\
\hline 28 & Chełm & $220.36^{\mathrm{abcd}}$ & (14.19) & 31.3 & 1.00 & $56.39^{\mathrm{abcd}}$ & $(2.77)$ & 7.0 & 0.98 \\
\hline 29 & Syców & $232.51^{\mathrm{abc}}$ & $(13.55)$ & 61.9 & 0.99 & $57.67^{\mathrm{abcd}}$ & $(2.35)$ & 0.6 & 1.00 \\
\hline 31 & Sieniawa $^{3}$ & $218.03^{\mathrm{abcd}}$ & (13.73) & 55.5 & 0.99 & $57.28^{\mathrm{abcd}}$ & $(2.39)$ & 0.8 & 1.00 \\
\hline 33 & Leżajsk & $220.22^{\mathrm{abcd}}$ & (13.86) & 36.7 & 0.99 & $58.22^{\mathrm{abcd}}$ & $(2.64)$ & 5.0 & 0.98 \\
\hline 34 & IDPAN & $235.64^{\mathrm{abc}}$ & $(14.62)$ & 91.6 & 0.99 & $61.31^{\mathrm{a}}$ & $(2.96)$ & 0.1 & 1.00 \\
\hline 35 & Choczewo (Lębork) $)^{1 *}$ & $234.47^{\mathrm{abc}}$ & $(15.10)$ & 13.1 & 1.00 & $59.71^{\mathrm{ab}}$ & $(2.80)$ & 9.0 & 0.97 \\
\hline 36 & Gołdap (Suwałki)* & $216.64^{\text {bcd }}$ & $(13.62)$ & 121.0 & 0.98 & $57.48^{\mathrm{abcd}}$ & $(2.79)$ & 12.0 & 0.96 \\
\hline 37 & Kórnik (Babki)* & $217.02^{\mathrm{bcd}}$ & $(15.52)$ & 55.1 & 0.99 & $58.89^{\mathrm{abc}}$ & $(2.63)$ & 3.2 & 0.99 \\
\hline 38 & Janów Lub. ${ }^{3} *$ & $204.39^{\text {de }}$ & $(13.69)$ & 330.1 & 0.95 & $55.32^{\text {bcd }}$ & $(2.47)$ & 15.2 & 0.93 \\
\hline 39 & Wymiarki* & $238.87^{\mathrm{ab}}$ & $(15.14)$ & 187.5 & 0.98 & $59.15^{\mathrm{abc}}$ & $(2.55)$ & 1.3 & 0.99 \\
\hline Mean & & 226.11 & $(2.42)$ & & & 57.99 & $(0.45)$ & & \\
\hline \multirow[t]{2}{*}{ ANOVA } & \multicolumn{4}{|c|}{ Tree height at age 8 years } & & \multicolumn{4}{|c|}{ Tree DBH at age 13 years } \\
\hline & \multicolumn{2}{|l|}{$d f$} & \multicolumn{3}{|l|}{$P>F$} & \multicolumn{2}{|l|}{$d f$} & \multicolumn{2}{|l|}{$P>F$} \\
\hline Site & \multicolumn{2}{|l|}{4} & \multicolumn{3}{|l|}{$<0.0001$} & \multicolumn{2}{|l|}{4} & \multicolumn{2}{|l|}{$<0.0001$} \\
\hline Block(Site) & \multicolumn{2}{|l|}{20} & \multicolumn{3}{|l|}{$<0.0001$} & \multicolumn{2}{|l|}{20} & \multicolumn{2}{|l|}{$<0.0001$} \\
\hline Population & \multicolumn{2}{|l|}{35} & \multicolumn{3}{|l|}{$<0.0001$} & \multicolumn{2}{|l|}{35} & $<0.0001$ & \\
\hline Pop. $\times$ Site & 140 & & $<0.0001$ & & & 140 & & 0.0008 & \\
\hline
\end{tabular}


Table 1 continued

\begin{tabular}{llll}
\hline ANOVA & Tree height at age 8 years & Tree DBH at age 13 years \\
\cline { 2 - 3 } & $d f$ & $P>F$ & df \\
\hline Error & 700 & 700 & $P>F$ \\
\hline
\end{tabular}

Values connected with the same superscript letters are not significantly different for a given trait at the $\alpha=0.05$ in the Tukey-Kramer HSD test. The corresponding ANOVA $P$ values are given at the bottom of the table

Superscript numbers indicate organization of selected populations into the predefined groups based on final leader length during the 5th growing season at the Kórnik site: ${ }^{1}$ long, ${ }^{2}$ average, ${ }^{3}$ short

* Progeny of commercial seed stands local to the planting sites

Similar measurements of shoot growth rhythm were done during the 6th growing season (2003) on the subset of nine populations. The subset consisted of three groups by three populations that were selected based on their final shoot length from the previous year-long, average and short (Tables 1, 3). Measurements started on April 17 (107th day of year) and continued about bi-weekly until the end of shoot elongation on July 10 (191 day of year). Three trees per plot were measured for the total of 81 trees. The procedure was the same as above.

Shoot growth data were ln-transformed, and the Richards function (Causton et al. 1978; Richards 1959) was fit at the plot level. The Richards function is a four-parameter equation that describes well a nonlinearity of plant growth. Its properties and applications in plant growth analysis have been reviewed in Hunt 1982. The validity of fitted model was judged based on the $R^{2}$ value and a distribution of residuals. The fitted parameters from Richards function were used to derive the final leader length and the weighted mean relative growth rate (RGR) (Causton et al. 1978; Hunt 1982). The time when $10 \%$ (START DAY) and 90\% (END DAY) of the final leader length was completed was derived from the graph, and the time distance between those two points was assumed to reflect shoot elongation time.

During the 6th growing season (2003), needles were collected on the above-mentioned subset of nine populations. Collections started on May 29 (149th day of year) and continued in weekly or bi-weekly intervals until November 27 (331st day of year). Needles from the middle of leader shoots were collected from 10 trees and combined into a plot-level sample. A sub-sample of 6 fascicles was taken for the measurements of needle length, projected area, and fresh and dry mass (after oven-drying at $65^{\circ} \mathrm{C}$ for at least $48 \mathrm{~h}$ to a constant weight). Specific leaf area (SLA, $\mathrm{m}^{2} \mathrm{~kg}^{-1}$ ) was calculated based on a projected area that was measured with the WinRHIZO ${ }^{\circledR}$ software and a calibrated scanner (Regent Instruments Inc., Canada). A subset of needles were oven-dried, ground to fine powder and analyzed for nitrogen $(\mathrm{N})$ and carbon $(\mathrm{C})$ concentration with the Flash EA1112 NC analyzer (Thermo Finnigan). Needle $\mathrm{N}$ concentration was calculated on the mass and area basis.
Unfortunately, due to a sampling error, needles collected between June 18 and July 17 (3 collections) had to be discarded.

Spring bud burst phenology was assessed by observation of vegetative buds on a single occasion during a growing season when most plants burst their buds, and the differences among populations were most visible. This method has been shown to result in data that correlate well with estimates obtained from repeated observations (von Wuehlisch et al. 1995) and is particularly useful for quantifying the relative differences among tested populations. Phenology observations were taken in the 8-step scale (from 1-dormant bud to 8-expanding shoot) by a single observer at all sites on one tree row per plot in three blocks.

Observations were made at the beginning of the $3 \mathrm{rd}$ growing season (2000) in Kórnik and Gołdap only. In spring 2002 and 2003, observations were taken at all five sites (except in Kórnik in 2002).

Statistical analysis

The plot mean inventory data from all sites were subject to the analysis of variance according to the model:

$Y_{i j k}=L_{i}+B_{j(i)}+P_{k}+P L_{i k}+e_{i j k}$

where $Y_{i j k}$ is the plot-level mean; $L_{i}$ is the effect of $i$ th site $(i=1, \ldots, 5) ; B_{j(i)}$ is the effect of $j$ th block within the $i$ th site $(j=1, \ldots, 5) ; P_{k}$ is the effect of $k$ th population $(k=1, \ldots, 36)$; $P L_{i k}$ is the effect of interaction of $k$ th population with the $i$ th site; and $e_{i j k}$ is the error term. All terms except population were treated as random. Significance of the population term was tested with the $F$ test against the interaction mean square, and the block(site) and population $\times$ site interaction terms were tested against residual mean square. Plot-level percent data on survival were arcsine-corrected before the analysis to ensure normality of distribution and equality of variance. To account for the possible effect of thinning on growth traits, we also performed the analysis of covariance with the number of trees per plot as a covariate. We found little discrepancies between ANOVA and ANCOVA results; therefore, only ANOVA results are presented. 
In case of significant population $\times$ site interaction in growth traits - tree height and $\mathrm{DBH}$ - we used the regression approach to analyze population stability. Means of individual populations at each site were regressed on site means, and for each population, we derived regression coefficient $\left(b_{i}\right)$ (Finlay and Wilkinson 1963), deviations from regression $\left(s_{d i}^{2}\right)$ (Eberhart and Russell 1966) and the coefficient of determination $\left(R^{2}\right)$. Further, the ecovalence $\left(W_{i}\right)$ was calculated according to the formula given in Becker and Léon (1988).

A modification of model 1 was used to test for differences between two categories of genetic units tested-seed orchards and commercial seed stands; the two categories were used instead of populations. To test for similarities among genetically related populations, we used the Ward clustering method (Everitt 1980) based on growth data (tree height and DBH) at the population level.

The analysis of parameters derived from the Richards function and needle traits was performed at a single site (in Kórnik) according to the model:

$Y_{j k}=B_{j}+P_{k}+e_{j k}$

where $Y_{j k}$ is the plot-level mean; $B_{j}$ is the effect of $j$ th block $(j=1, \ldots, 3) ; \quad P_{k}$ is the effect of $k$ th population ( $k=1, \ldots, 36)$; and $e_{j k}$ is the error term. Significance of all effects was tested with the $F$ test against the residual mean square term.

Time trends in needle traits measured at the Kórnik site in 2003 were analyzed using repeated measures mixed model REML (Restricted Maximum Likelihood) method to account for dependency among subsequent measurements. Populations, time of measurement and population $\times$ time interaction terms were treated as fixed effects, and the plots nested within populations were treated as random effect. The same analysis was performed for the predefined groups of populations.

To ensure normality of distribution and equality of variance, the plot mean values of bud burst were standardized within each site (plot mean minus the site mean divided by the site standard deviation). This procedure reduces variation among sites to zero. After standardization, the positive values indicate an earlier bud burst, and negative values indicate a later bud burst in standard deviation units. Separate analyses for bud burst were performed at each site and assessment period, according to model 2. The number of sites analyzed for spring phenology varied from 2 in 2000, to 4 in 2002 and 5 in 2003. Subsequently, populations were grouped with the Ward clustering method based on sites and assessment periods where differences among populations were significant $(P \leq 0.05)$. Standardized values of the reciprocal of START DAY in 2002 at the Kórnik site were used as an approximation of spring growth phenology for the clustering and correlation analysis.
Analysis of Pearson correlation or linear regression was used where appropriate to examine relationships between traits, between years and across years and sites. All statistical analyses were done with the JMP 9.0.0 software (SAS Institute Inc., Cary, NC).

\section{Results}

Survival and growth traits

Survival at age 4 varied significantly among sites $(P<0.0001)$ and was higher at the Kórnik site $(91 \%)$ than at four other sites ( $72 \%$ on average), and also higher in Janów Lubelski (78\%) and Wymiarki (74\%) than in Gołdap (66\%). Similarly, survival varied among sites at age 8 years, and again survival at the Kórnik site $(88 \%)$ was significantly greater than at other sites. Survival in Janów Lubelski (67\%) and Wymiarki (72\%) was significantly greater than in Choczewo (50\%) and Gołdap (50\%). Population differences were significant only at age 8 years $(P=0.0004)$ when survival varied from $59 \%$ for population Miechów (21) to $73 \%$ for population Supraśl (1).

All sources of variation (see model 1) were significant for tree height at age 8 and $\mathrm{DBH}$ at age 13 (Table 1). Results for tree height at age 4 were described in the earlier paper (Chmura et al. 2003).

Site differences were significant for all the inventory traits (Table 2). Mean values at Kórnik and Choczewo sites were significantly greater than at three other locations. Differences between sites with the greatest and poorest growth were as large as 44 and $53 \%$ for tree height at ages 4 and 8 years, respectively, and $43 \%$ for $\mathrm{DBH}$ at age 13 years (Table 2 ).

Differences among populations were significant for tree height and DBH (Table 1). However, significant population $\times$ site interaction terms indicate that performance of populations varied across test sites. Therefore, additional measures were used to assess population performance stability. The results from the analysis of regression coefficients $\left(b_{i}\right)$ and ecovalence $\left(W_{i}\right)$ were summarized in Fig. 1, and deviations from regression $\left(s_{d i}^{2}\right)$ and the coefficient of determination $\left(R^{2}\right)$ values were given in Table 1.

The mean square for linear regression effect partitioned from the population $\times$ site interaction term was significant for tree height at age 4 and DBH at age $13(P \leq 0.0083)$. The regression on site means gave a very good fit for most populations. The lowest $R^{2}$ values were noted for population Janów Lubelski (38; Table 1). For most populations, the regression coefficients $\left(b_{i}\right)$ did not significantly differ from 1.0 (top-row panels in Fig. 1), indicating that these populations had average responsiveness to change in the environmental conditions. The analysis of $W_{i}$ values helps 
Table 2 Means and standard errors (SE) of inventory traits at five experimental sites and the ranking positions of local commercial seed stands within the tested 36 populations at each site (see also Table 1)

\begin{tabular}{lllllll}
\hline Site & $\begin{array}{l}\text { Tree height } \\
\text { at age } 4(\mathrm{~cm})\end{array}$ & $\begin{array}{l}\text { Rank of local } \\
\text { population }\end{array}$ & $\begin{array}{l}\text { Tree height at } \\
\text { age } 8(\mathrm{~cm})\end{array}$ & $\begin{array}{l}\text { Rank of local } \\
\text { population }\end{array}$ & $\begin{array}{c}\text { Tree DBH at age 13 (mm) } \\
\text { Rank of local } \\
\text { population }\end{array}$ \\
\hline Wymiarki & $47.5^{\mathrm{c}}(1.29)$ & 1 & $191.3^{\mathrm{c}}(3.95)$ & 3 & $43.8^{\mathrm{d}}(0.56)$ & 8 \\
Janów Lub. & $49.2^{\mathrm{c}}(1.21)$ & 22 & $164.3^{\mathrm{d}}(3.90)$ & 29 & $43.1^{\mathrm{d}}(0.69)$ & 35 \\
Gołdap & $41.5^{\mathrm{d}}(1.32)$ & 33 & $166.0^{\mathrm{d}}(4.72)$ & 31 & $61.2^{\mathrm{c}}(0.68)$ & 34 \\
Choczewo & $61.5^{\mathrm{b}}(1.25)$ & 8 & $266.7^{\mathrm{b}}(4.40)$ & 11 & $75.4^{\mathrm{a}}(0.72)$ & 16 \\
Kórnik & $74.2^{\mathrm{a}}(1.09)$ & 10 & $342.2^{\mathrm{a}}(3.31)$ & 19 & $66.4^{\mathrm{b}}(0.65)$ & 18 \\
\hline
\end{tabular}

Site means connected with the same superscript letters are not significantly different for a given trait at the $\alpha=0.05$ in the Tukey-Kramer HSD test
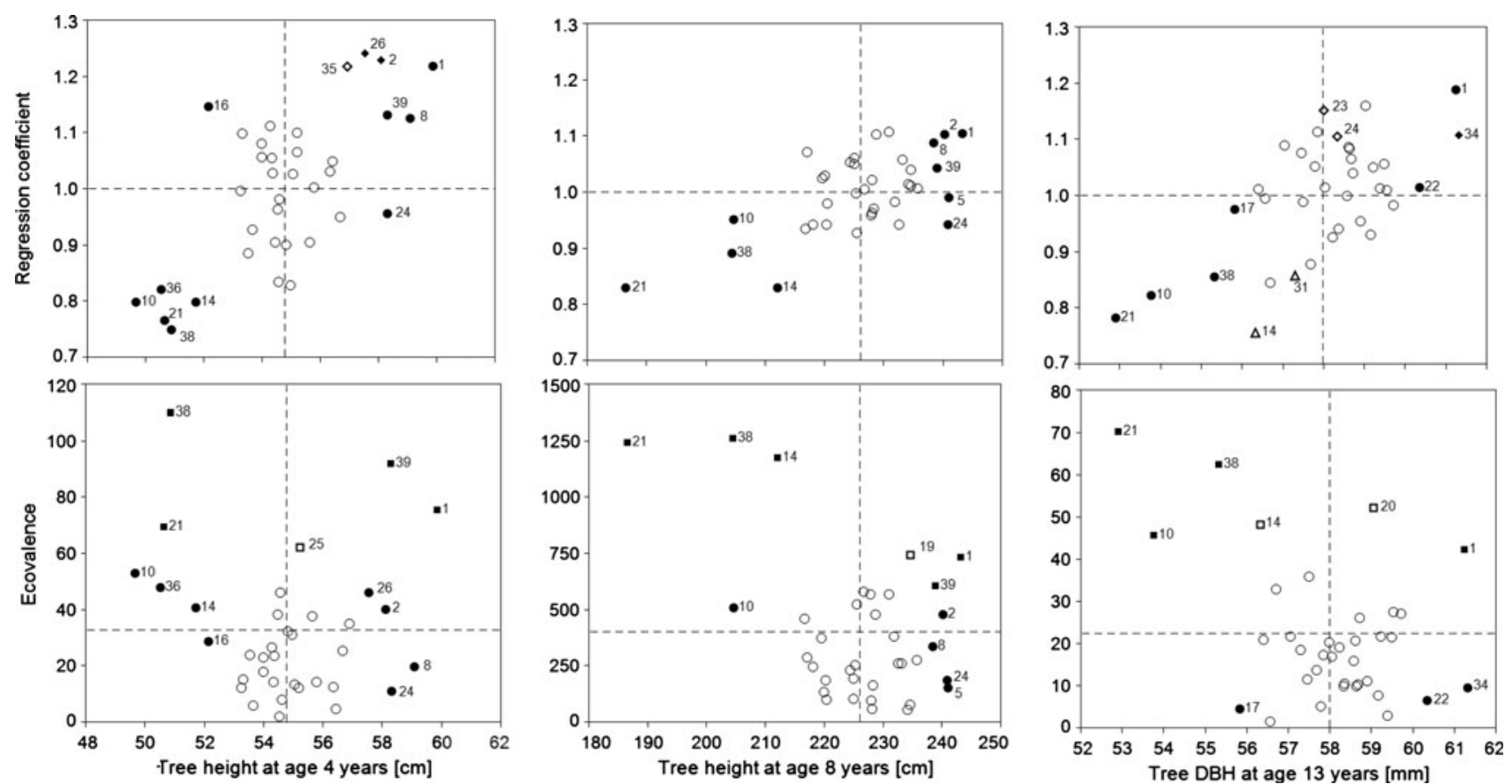

Fig. 1 Regression coefficients $\left(b_{i}\right)$ and ecovalence $\left(W_{i}\right)$ graphed against population means for tree heights at age 4 and 8 years and DBH at age 13 years. Each point represents a population mean based on results from five experimental sites. Dashed lines show overall means. Filled symbols show populations whose means were at least one standard deviation greater or smaller than the overall mean

to identify populations with a large contribution to the $\mathrm{G} \times \mathrm{E}$ interaction as indicated at the bottom-row panels in Fig. 1. When populations indicated with squares in Fig. 1 were excluded from the analysis, the interaction was effectively reduced, and the population $\times$ site effect was no longer statistically significant, except for tree height at age 4 years. A set of the most interactive populations varied slightly by trait and age, but overall populations from Miechów (21), Janów Lubelski (38) Runowo 1 (10), and Józefów (14) at the low end of the population ranking, and Supraśl (1) at the high end, contributed the most to the $\mathrm{G} \times \mathrm{E}$ interaction (Fig. 1). The ecovalence values showed (numbers correspond to population identifiers in Table 1). In the toprow panels, diamonds and triangles indicate populations whose $b_{i}$ values were significantly greater or smaller than 1.0 , respectively. In the bottom-row panels, squares indicate populations contributing the most to the $\mathrm{G} \times \mathrm{E}$ interaction

significant positive correlations with $s_{d i}^{2}$ ( $r$ from 0.73 to $0.87, P<0.0001, n=36$ ), but the $s_{d i}^{2}$ values were not significantly different from zero for any population (Table 1).

Clustering of populations based on growth data resulted in only two relevant clusters. Values for Orneta (8) were close to those for Susz (19), and values for Świdnik (25) were close to Sieniawa (31; see Methods). The other presumably related populations were not clustered into uniform groups; thus, these results were inconclusive. Comparing growth performance among probably related populations, some differences were observed, although 
never statistically significant. Population Runowo1 (10) performed relatively poorer compared with other related populations (Runowo 2-4 (11-13), Gniewkowo (2); Table 1). Similar results were observed for Józefów (14, tree height only) when compared with Świdnik (25), Sieniawa (31) and Leżajsk (33), for Sulechów 2 (17) when compared with Orneta (7) and Susz (19) and for Kwidzyn 1 (22) compared with Zaporowo (8, tree height only); Table 1).

In the analysis of two categories of genetic units, we found no significant differences between progeny of seed orchards and commercial seed stands in survival and measured growth traits. In addition, progeny of local commercial seed stands was not always the best for their planting sites. Only the population Wymiarki (39) and partially Choczewo (35) ranked high in terms of tree height and diameter at their local sites, whereas at other sites, the local seed sources were only average or even close to the bottom of the rank (Table 2).

Growth rhythm dynamics and needle traits at the Kórnik site

Richards function fitted well to measurement data at the Kórnik site. The $R^{2}$ varied between 0.987 and 0.997 for individual plots in 2002 for all populations, and between 0.996 and 0.999 in 2003 for the subset of populations. However, this function tended to underestimate leader length values at the beginning of the growing season [up to $26 \%$ underestimation for populations Gniezno (5), Syców (29) and Janów Lubelski (38)].

In 2002, populations differed significantly in the final length of leader shoot and the weighted mean RGR. Trees in population Skierniewice (6) had the longest leader shoots-28 to $37 \%$ longer than in three populations with shortest leaders-Gołdap (36), Janów Lubelski (38) and Miechów (21; Table 3). Trees from population Miechów had significantly $(P<0.05)$ shorter leaders than half of the tested populations and also had lower weighted mean RGR than the seven best-growing seed sources (Table 3). Differences among populations were also significant for the shoot elongation time (Table 3), and START DAY $(P=0.0001)$, but not END DAY $(P=0.0783)$.

In 2003, when only a subset of populations was measured, differences among populations were significant only for RGR (Table 3) and END DAY $(P=0.0373)$. In a comparison among the predefined groups, the only significant difference was found for the final leader length $(P=0.0031)$ where the mean of the "long" group was greater than the mean of the "short" group (see Table 3). The correlation between years 2002 and 2003 in growth rhythm traits was significant only for the leader length $(r=0.87, P=0.0022, n=9)$.

Needle growth, morphology and $\mathrm{N}$ concentration dynamics was assessed on a subset of populations in 2003.
No significant population $\times$ time or group $\times$ time interaction was found for needle length, needle dry mass, SLA or foliar nitrogen, meaning that time trends in these traits were the same for all sampled populations and predefined groups of populations (Fig. 2). Population effect was significant only for the foliar $\mathrm{N}$ on mass $(P=0.0097)$ and area basis $(P=0.0145)$, but group effect was not significant for any needle trait.

Time had a significant effect $(P<0.0001)$ on all needle traits analyzed. Final needle length and needle dry mass were attained on average by July 31 (day 212) and August 14 (day 226), respectively (Fig. 2). Measurement from three collections was excluded from the analysis. However, half of the final needle length was attained before the period of exclusion by June 12 (day 163) for all populations in the subset (Fig. 2).

Specific leaf area (SLA) declined from the maximum values at the first collection on May 29 (day 149) to the value of about $44 \%$ of the maximum attained at day 301 (October 28), and stayed at that level to the end of sampling period (Fig. 2).

Needle nitrogen on mass basis declined from the maximum values at the beginning of sampling period on May 29 (day 149) to its lowest values on July 31 (day 212) when it was about $60 \%$ of maximum, and stayed at this level for at least 4 weeks until August 29 (day 241; Fig. 2). Subsequently, leaf $\mathrm{N}$ concentration increased to the level of about $75 \%$ of maximum on September 25 (day 268) and remained at this level to the end of needle sampling in November (Fig. 2). On average, the population Supraśl (1) had lower foliar $\mathrm{N}$ concentration than trees from Bierzwnik (18) and Choczewo (35).

Foliar $\mathrm{N}$ on area basis increased from the value of 3.13 (3.01-3.35) $\mathrm{g} \mathrm{m}^{-2}$ (mean and 95\% confidence limits) at first collection to 4.94 (4.76-5.13) $\mathrm{g} \mathrm{m}^{-2}$ on September 25 (day 268 ), and continued to increase, although not significantly, to the end of sampling (final value 5.40; 5.20-5.61 $\mathrm{g} \mathrm{m}^{-2}$ ). On average, the population Supraśl (1) had a lower area-based foliar N than trees from Miechów (21), Bierzwnik (18), Janów Lubelski (38) and Sulechów 1 (16).

Relationships between growth rhythm variables, needle traits and tree growth

Variation in the final leader length may arise from differences in growth rate, shoot elongation time or both. In our study, shoot elongation time explained more variation in leader length $\left(R^{2}=0.27, P=0.0013\right)$ than $\operatorname{did} \mathrm{RGR}\left(R^{2}=0.21\right.$, $P=0.0042)$ in 2002. However, the negative relationship between shoot elongation time and leader length indicate that trees with shorter leaders tended to grow for a longer time. In 2003, correlations between shoot elongation time, RGR and leader length were weak and nonsignificant. 
Table 3 Values of average leader length, weighted mean RGR and shoot elongation time measured at the Kórnik site during the 5th growing season (2002) for all 36 Scots pine populations, and leader length and RGR for the subset of populations measured in the 6th growing season (2003)

\begin{tabular}{|c|c|c|c|c|c|c|}
\hline $\begin{array}{l}\text { ID } \\
\text { number }\end{array}$ & $\begin{array}{l}\text { Population } \\
\text { name }\end{array}$ & $\begin{array}{l}\text { Final leader length } \\
\text { in } 5 \text { th growing } \\
\text { season }(\mathrm{cm})\end{array}$ & $\begin{array}{l}\text { Relative Growth } \\
\text { Rate in } 5 \text { th } \\
\text { growing season } \\
\left(\mathrm{mm} \mathrm{mm} \mathrm{mm}^{-1} \text { day }^{-1}\right)\end{array}$ & $\begin{array}{l}\text { Shoot elongation } \\
\text { time in 5th } \\
\text { growing season } \\
\text { (days) }\end{array}$ & $\begin{array}{l}\text { Final leader } \\
\text { length in 6th } \\
\text { growing season } \\
(\mathrm{cm})\end{array}$ & $\begin{array}{l}\text { Relative Growth } \\
\text { Rate in 6th growing } \\
\text { season } \\
\left(\mathrm{mm} \mathrm{mm} \mathrm{mm}^{-1} \text { day }^{-1}\right)\end{array}$ \\
\hline 1 & Supraśl $^{1}$ & $59.8^{\mathrm{ab}}(53.3-67.0)$ & $0.51^{\mathrm{abcd}}(0.49-0.53)$ & $37.7^{\mathrm{abcd}}(36.6-38.8)$ & $69.9^{\mathrm{a}}(58.9-83.0)$ & $0.69^{\mathrm{ab}}(0.66-0.72)$ \\
\hline 2 & Gniewkowo $^{2}$ & $53.2^{\mathrm{abc}}(47.5-59.6)$ & $0.52^{\mathrm{abcd}}(0.50-0.54)$ & $37.3^{\text {abcd }}(36.2-38.4)$ & $66.4^{\mathrm{a}}(55.9-78.8)$ & $0.72^{\mathrm{ab}}(0.68-0.75)$ \\
\hline 3 & Dwukoły & $54.2^{\mathrm{abc}}(48.4-60.8)$ & $0.50^{\text {bcd }}(0.48-0.52)$ & $38.3^{\text {bac }}(37.2-39.4)$ & & \\
\hline 4 & Międzylesie & $59.2^{\mathrm{ab}}(52.8-66.4)$ & $0.51^{\text {abcd }}(0.49-0.53)$ & $37.7^{\text {abcd }}(36.6-38.8)$ & & \\
\hline 5 & Gniezno & $57.4^{\mathrm{ab}}(51.2-64.3)$ & $0.57^{\mathrm{a}}(0.54-0.59)$ & $34.7^{\mathrm{d}}(33.6-35.8)$ & & \\
\hline 6 & Skierniewice $^{1}$ & $63.7^{\mathrm{a}}(56.8-71.4)$ & $0.51^{\text {abcd }}(0.49-0.53)$ & $38.0^{\mathrm{abc}}(36.9-39.1)$ & $71.6^{\mathrm{a}}(60.3-85.0)$ & $0.69^{\mathrm{ab}}(0.66-0.72)$ \\
\hline 7 & Orneta & $53.0^{\mathrm{abc}}(47.3-59.5)$ & $0.50^{\text {bcd }}(0.48-0.52)$ & $38.7^{\mathrm{abc}}(37.6-39.8)$ & & \\
\hline 8 & Zaporowo & $59.1^{\mathrm{ab}}(52.8-66.3)$ & $0.51^{\mathrm{abcd}}(0.48-0.53)$ & $38.0^{\mathrm{abc}}(36.9-39.1)$ & & \\
\hline 10 & Runowo 1 & $52.3^{\mathrm{abc}}(46.7-58.6)$ & $0.53^{\mathrm{abcd}}(0.50-0.55)$ & $37.0^{\text {bcd }}(35.9-38.1)$ & & \\
\hline 11 & Runowo 2 & $58.3^{\mathrm{ab}}(52.1-65.4)$ & $0.53^{\mathrm{abcd}}(0.51-0.55)$ & $37.0^{\text {bcd }}(35.9-38.1)$ & & \\
\hline 12 & Runowo 3 & $61.3^{\mathrm{ab}}(54.7-68.7)$ & $0.50^{\text {bcd }}(0.48-0.52)$ & $38.3^{\mathrm{abc}}(37.2-39.4)$ & & \\
\hline 13 & Runowo 4 & $57.4^{\mathrm{ab}}(51.2-64.3)$ & $0.52^{\text {abcd }}(0.50-0.54)$ & $37.3^{\text {abcd }}(36.2-38.4)$ & & \\
\hline 14 & Józefów & $53.4^{\mathrm{abc}}(47.7-59.9)$ & $0.53^{\text {abcd }}(0.51-0.55)$ & $36.3^{\text {bcd }}(35.2-37.4)$ & & \\
\hline 15 & Brzeg & $59.5^{\mathrm{ab}}(53.1-66.7)$ & $0.52^{\text {abcd }}(0.49-0.54)$ & $37.3^{\text {abcd }}(36.2-38.4)$ & & \\
\hline 16 & Sulechów $1^{2}$ & $55.2^{\mathrm{ab}}(49.3-61.9)$ & $0.53^{\text {abcd }}(0.50-0.55)$ & $37.0^{\text {bcd }}(35.9-38.1)$ & $59.6^{\mathrm{a}}(50.2-70.8)$ & $0.65^{\mathrm{b}}(0.62-0.68)$ \\
\hline 17 & Sulechów 2 & $55.9^{\mathrm{ab}}(49.9-62.7)$ & $0.51^{\text {abcd }}(0.49-0.53)$ & $37.7^{\text {abcd }}(36.6-38.8)$ & & \\
\hline 18 & Bierzwnik $^{2}$ & $54.4^{\mathrm{abc}}(48.6-61.0)$ & $0.52^{\mathrm{abcd}}(0.49-0.54)$ & $37.3^{\text {abcd }}(36.2-38.4)$ & $64.8^{\mathrm{a}}(54.6-77.0)$ & $0.70^{\mathrm{ab}}(0.67-0.73)$ \\
\hline 19 & Susz & $55.1^{\mathrm{abc}}(49.1-61.7)$ & $0.51^{\text {abcd }}(0.49-0.53)$ & $37.7^{\text {abcd }}(36.6-38.8)$ & & \\
\hline 20 & Nowogard & $58.7^{\mathrm{ab}}(52.4-65.8)$ & $0.54^{\mathrm{abc}}(0.52-0.56)$ & $36.3^{\text {bcd }}(35.2-37.4)$ & & \\
\hline 21 & Miechów ${ }^{3}$ & $39.9^{\mathrm{c}}(35.6-44.8)$ & $0.47^{\mathrm{d}}(0.45-0.49)$ & $40.3^{\mathrm{a}}(39.2-41.4)$ & $56.1^{\mathrm{a}}(47.3-66.6)$ & $0.71^{\mathrm{ab}}(0.67-0.74)$ \\
\hline 22 & Kwidzyn 1 & $55.2^{\mathrm{abc}}(49.3-61.9)$ & $0.50^{\text {bcd }}(0.48-0.52)$ & $37.3^{\text {abcd }}(36.2-38.4)$ & & \\
\hline 23 & Kwidzyn 2 & $54.9^{\mathrm{abc}}(49.0-61.5)$ & $0.50^{\text {bcd }}(0.48-0.52)$ & $38.0^{\mathrm{abc}}(36.9-39.1)$ & & \\
\hline 24 & Zdrojowa Góra & $61.3^{\mathrm{ab}}(54.7-68.7)$ & $0.54^{\mathrm{abc}}(0.51-0.56)$ & $36.7^{\text {bcd }}(35.6-37.8)$ & & \\
\hline 25 & Świdnik & $58.1^{\mathrm{ab}}(51.8-65.1)$ & $0.52^{\text {abcd }}(0.50-0.55)$ & $37.0^{\text {bcd }}(35.9-38.1)$ & & \\
\hline 26 & Biała & $59.7^{\mathrm{ab}}(53.3-67.0)$ & $0.53^{\text {abcd }}(0.51-0.56)$ & $36.7^{\text {bcd }}(35.6-37.8)$ & & \\
\hline 27 & Oborniki Śl. & $58.1^{\mathrm{ab}}(51.9-65.2)$ & $0.53^{\text {abcd }}(0.51-0.55)$ & $36.0^{\text {cd }}(34.9-37.1)$ & & \\
\hline 28 & Chełm & $53.3^{\mathrm{abc}}(47.5-59.7)$ & $0.52^{\text {abcd }}(0.49-0.54)$ & $37.7^{\text {abcd }}(36.6-38.8)$ & & \\
\hline 29 & Syców & $55.1^{\mathrm{abc}}(49.2-61.8)$ & $0.54^{\mathrm{abc}}(0.52-0.56)$ & $36.0^{\mathrm{cd}}(34.9-37.1)$ & & \\
\hline 31 & Sieniawa $^{3}$ & $49.0^{\mathrm{abc}}(43.8-55.0)$ & $0.48^{\mathrm{cd}}(0.46-0.50)$ & $39.3^{\mathrm{ab}}(38.2-40.4)$ & $56.1^{\mathrm{a}}(47.2-66.6)$ & $0.66^{\mathrm{ab}}(0.63-0.70)$ \\
\hline 33 & Leżajsk & $51.1^{\mathrm{abc}}(45.6-57.3)$ & $0.49^{\text {bcd }}(0.47-0.51)$ & $38.7^{\mathrm{abc}}(37.6-39.8)$ & & \\
\hline 34 & IDPAN & $57.8^{\mathrm{ab}}(51.5-64.7)$ & $0.53^{\mathrm{abcd}}(0.51-0.55)$ & $37.3^{\text {abcd }}(36.2-38.4)$ & & \\
\hline 35 & Choczewo $^{1}$ & $60.5^{\mathrm{ab}}(54.0-67.8)$ & $0.54^{\mathrm{abc}}(0.52-0.56)$ & $36.3^{\text {bcd }}(35.2-37.4)$ & $67.5^{\mathrm{a}}(56.8-80.1)$ & $0.70^{\mathrm{ab}}(0.67-0.73)$ \\
\hline 36 & Gołdap & $45.8^{\mathrm{bc}}(40.9-51.4)$ & $0.50^{\text {bcd }}(0.48-0.53)$ & $38.3^{\mathrm{abc}}(37.2-39.4)$ & & \\
\hline 37 & Kórnik & $50.5^{\mathrm{abc}}(45.0-56.5)$ & $0.54^{\mathrm{abc}}(0.52-0.56)$ & $36.7^{\mathrm{bcd}}(35.6-37.8)$ & & \\
\hline 38 & Janów Lub. ${ }^{3}$ & $45.3^{\mathrm{bc}}(40.5-50.8)$ & $0.51^{\mathrm{abcd}}(0.49-0.53)$ & $38.0^{\mathrm{abc}}(36.9-39.1)$ & $54.2^{\mathrm{a}}(45.7-64.4)$ & $0.73^{\mathrm{a}}(0.70-0.76)$ \\
\hline 39 & Wymiarki & $55.8^{\mathrm{ab}}(49.8-62.6)$ & $0.55^{\mathrm{ab}}(0.53-0.57)$ & $36.0^{\text {cd }}(34.9-37.1)$ & & \\
\hline ANOVA & $d f$ & $P>F$ & $P>F$ & $P>F$ & $P>F$ & $P>F$ \\
\hline Block & 2 & 0.5401 & 0.7499 & 0.675 & 0.6133 & 0.3414 \\
\hline Population & 35 & 0.0002 & $<0.0001$ & $<0.0001$ & 0.1819 & 0.0472 \\
\hline Error & 70 & 70 & 70 & & 16 & 16 \\
\hline
\end{tabular}

Upper and lower $95 \%$ confidence intervals are given in parentheses. Populations connected with the same superscript letters are not significantly different for a given trait at the $\alpha=0.05$ in the Tukey-Kramer HSD test. The corresponding ANOVA $P$ values are given at the bottom of the table

Superscript numbers indicate organization of selected populations into the predefined groups based on final leader length during the 5th growing season at the Kórnik site: ${ }^{1}$ long, ${ }^{2}$ average, ${ }^{3}$ short 

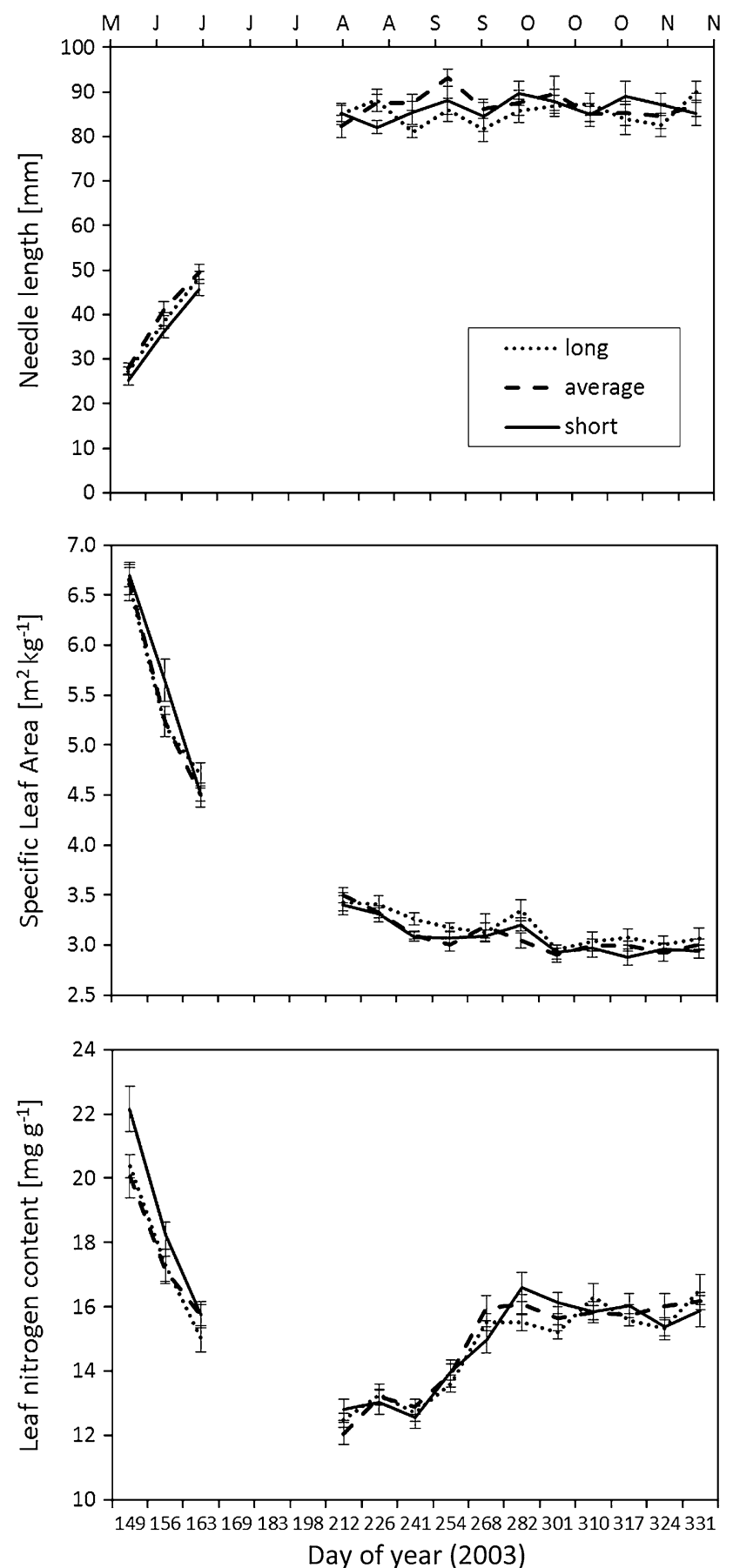

Fig. 2 Dynamics of needle length, specific leaf area (SLA) and leaf nitrogen on mass basis during the 6th growing season at the Kórnik experimental site. Means and standard errors (bars) for three predefined groups of populations at each collection time are shown ( $n=9$ per group at each point). The groups of populations were selected based on shoot growth measurements during the previous growing season. Data are presented in the original scale, but $\mathrm{ln}$ transformed data were analyzed

Leader length was responsible for most of the observed variation in tree height at ages $5\left(2002, R^{2}=0.75\right.$, $P<0.0001)$ and 6 years $\left(2003, R^{2}=0.77, P=0.0019\right)$ at the Kórnik site. No other factors, such as RGR, shoot elongation time, START DAY or END DAY, showed a significant linear relationship with tree height in 2002. Similarly, in 2003, RGR was not a significant factor in the analysis of variation in tree height in our study. However, tree height was significantly correlated with the final values of SLA $(r=0.68$, $P=0.0447, n=9)$, START DAY $(r=-0.74, P=0.0214$, $n=9)$ and foliar $\mathrm{N}$ on leaf area basis $(r=-0.71$, $P=0.0323, n=9)$ in 2003. We found no significant correlation between any leaf trait (final values of SLA, leaf N, leaf length and leaf mass) and RGR at the population level.

The shoot elongation time was more strongly related to START DAY (Pearson $r=-0.90, P<0.0001, n=36$ ) than to END DAY in $2002(r=-0.32, P=0.0562$, $n=36$ ). In contrast, in 2003, correlation was strong and positive between shoot elongation time and END DAY $(r=0.82, P=0.0071, n=9)$, but not START DAY $(r=0.20, P=0.6265, n=9)$.

\section{Bud burst phenology}

Differences in bud burst were statistically significant $(P \leq 0.05)$ among populations at all assessment periods and sites, except in spring 2000 at the Gołdap site and in 2002 at the Janów Lubelski site.

Correlations of phenology observations between years 2002 and 2003 were positive and significant when analyzed separately at all sites ( $r$ varied between 0.46 and 0.81 , $P \leq 0.0049$ ), except in Kórnik. At that latter site, the reciprocal of START DAY was used as an approximation of bud burst in 2002, which also showed a weak correlation with bud burst observation in 2000. Thus, three outlier populations were excluded [Miechów (21), Sieniawa (31) and Leżajsk (33)], and the correlations improved to 0.64 and $0.43(P \leq 0.0131)$ for $2000 / 2002$ and $2002 / 2003$, respectively, at the Kórnik site. No correlation was also found between phenology observations in 2000 and 2002 or 2003 in Gołdap. Those early observations at the Gołdap site possibly differed from the inherent pattern of bud burst for tested populations, because correlations across other sites and assessment periods were positive and significant ( $r$ between 0.46 and $0.72, P \leq 0.0252$ ), with just a few exceptions (4 out of remaining 56 correlations).

The correlations between bud burst observations and growth traits were weak to medium. The highest value of Pearson $r=0.41(P<0.0001, n=180)$ was found between bud burst observation in 2003 (age 6 years) and tree height in 2005 (age 8 years) across all sites, indicating that early budbursting trees tended to show stronger height growth. The strongest correlations between spring phenology and tree growth were found at the Choczewo site for both tree height and diameter, whereas no significant correlation was found in Wymiarki. 
Clustering of populations based on bud burst was performed using sites and years where population variation was statistically significant. The three outlier populations at the Kórnik site were not used in cluster analysis. Clustering revealed three groups of populations differing in bud burst, and those results were related to geographic distribution of populations, and possibly, to genetic relatedness between some of them. Figure 3 summarizes findings from the cluster analysis and presents average values of bud burst in standard deviation units for the three identified groups. The early budbursting populations originated from the north-eastern to north-central Poland. A group of late bud-bursting populations was located mainly in the south-eastern region, and four out of eight populations in this cluster were likely genetically related. The only early bud-bursting population in the southMiędzylesie (4) —was of montane origin. The western populations were intermediate, although two seed sources from that region [Nowogard 20 and Oborniki Śl. (27)] fell into a group of late bud-bursting populations (Fig. 3).

\section{Discussion}

Population variation in growth traits

In a network of five common garden trials, we found significant variation among tested progenies of Scots pine in terms of tree height and diameter throughout 13 years in the field. On average, the differences between the best and

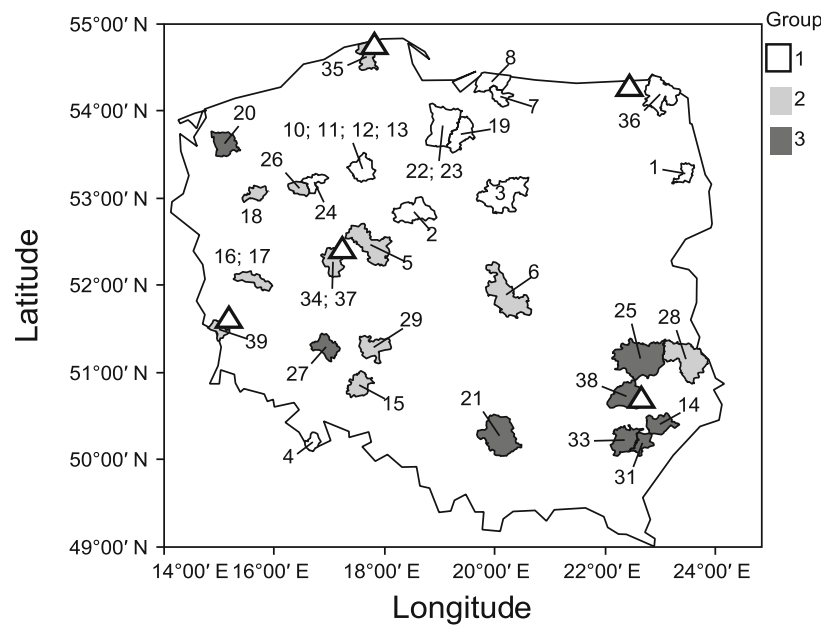

Fig. 3 Average bud burst assessed in the common garden experiment with 36 Scots pine populations at five sites showed in standardized units. Means $\pm \mathrm{SD}$ for groups of populations were: Group $1=0.75 \pm 0.29$, Group $2=-0.14 \pm 0.28$ and Group $3=-$ $0.97 \pm 0.29$ (positive values indicate early bud burst and negative values indicate late bud burst). Numbers correspond to population identifiers in Table 1. Shaded areas show boundaries of forest enterprises where seed orchards or seed stands were located and may only roughly indicate the area of origin of parent trees. White-filled triangles show approximate locations of experimental sites worst-growing population reached $24 \%(57 \mathrm{~cm})$ for tree height at age 8 years, and $14 \%(8.4 \mathrm{~mm})$ for diameter at age 13 years.

We did not find significant differences in growth traits between progeny of seed orchards and commercial seed stands in our experiment. This finding, contradicting our hypothesis, is quite surprising. However, because the population effect was fixed in the model used in analysis, this result should not be extrapolated beyond our dataset. The lack of expected superiority of seed orchards' progeny most likely resulted from a phenotypic (mass) selection only applied to the plus trees in this study. Those plus trees were clonally propagated and established in seed orchards. The orchards have not been progeny-tested and rogued, thus the level of genetic variation may be similar within such seed orchards composed of phenotypically selected trees and the seed stands that were also phenotypically superior among the stands in their regions.

However, the seed stands were far from being uniform in our study. For example, seed stand progenies from Wymiarki (39) and Choczewo (35) grew well or average, whereas progenies from Gołdap (36) and Janów Lubelski (38) grew poorly. In case of a lack of information on genetic value of populations, it is often safe to assume that local seed sources will perform well because of their adaptation to local environments. It is clear from our results that progenies of local seed stands not always grew best and were even among the worse (see Table 2). Thus, it is possible to find seed sources that grow better than the local ones, and replicated field tests are essential for discerning such differences.

Site variation in growth traits

The differences among sites in growth traits were highly significant and even greater than variation among the populations (see Tables 1, 2). In general, tree height is a good indicator of site quality, for example, used as a site index for site classification (Baker 1950). Thus, site differences in tree height likely reflect variable site conditions in our study, especially at early age before the thinning. The first thinnings were done at age 8 years in Choczewo and Janów Lubelski. The improvement of site mean by both removal of the thinnest trees and the increased growth from release should be reflected especially in diameter growth. We found such an improvement at the Choczewo site, but not in Janów Lubelski (see Table 2). In fact, the Janów site had the lowest mean diameter, which together with rather poor tree height indicates particularly low growth potential at that site.

$\mathrm{G} \times \mathrm{E}$ interaction

A statistically significant interaction in growth traits was found between tested progenies and experimental sites in 
our study. This implies that populations performed differently across sites. Stability of performance may be one of the criteria for selection of varieties or populations. For example, one may select for stable populations that perform uniformly at a variety of sites or may be more interested in less stable populations that perform relatively better at more productive environments. These two strategies correspond to the static and dynamic concepts of stability, respectively (Becker and Léon 1988).

The regression (Eberhart and Russell 1966; Finlay and Wilkinson 1963) and ecovalence analysis (Wricke 1962) were successfully used to analyze stability of performance in Norway spruce clones (Isik and Kleinschmit 2003; St. Clair and Kleinschmit 1986) and provenances (Burczyk and Giertych 1991), provenances of Scots pine (Shutyaev and Giertych 1997; Shutyaev and Giertych 2000) and jack pine (Morgenstern and Teich 1969) and families of loblolly pine ( $\mathrm{Li}$ and McKeand 1989; Owino 1977; Yeiser et al. 2001). Those methods were also used in our study. The high and positive correlation between $W_{i}$ and $s_{d i}^{2}$ was consistent with findings in the literature (Becker 1981; Becker and Léon 1988), but on the whole, we found little variation in measures of stability in our dataset. Only a few $b_{i}$ values were statistically significant, meaning that most populations in our dataset had average responsiveness to changes in the environment (Becker and Léon 1988). The small variation in stability parameters may be a result of too small environmental variation among test sites (Eberhart and Russell 1966), although this seems unlikely given the site differences discussed above. Thus, despite significant $\mathrm{G} \times \mathrm{E}$ interaction, most populations showed average stability across sites.

The general interpretation of graphs shown in Fig. 1 allows identification of populations suitable for selection. The regression coefficients were not different from 1.0 for most populations; thus, selection would be perhaps safer (less restrictive), than in the presence of more unstable seed sources. The ideal populations would fall into a bottom right-hand corner of the panels in Fig. 1. Such populations would have a stable, above-average performance. However, the responsiveness of populations to environment varied by trait and age. Only one population stands out for both tree height and diameter-Supraśl (1), although it contributes relatively highly to the $\mathrm{G} \times \mathrm{E}$ interaction (see bottom panels of Fig. 1). Populations that should be considered for selection on tree height were Gniewkowo (5), Zaporowo (8) and Zdrojowa Góra (24), and for selection on diameter-Kwidzyn 1 (22) and IDPAN (34, see Fig. 1). There is also a group of populations with stable $\left(b_{i}<1.0\right)$ poor growth performance-Runowo1 (10), Miechów (21), Janów Lubelski (38) and Józefów (14) (see Fig. 1). This group of poor-performing populations seems to be relatively less responsive to improved environmental conditions. The deviations from site means for those populations were generally large compared with other seed sources, which is the reason for high $W_{i}$ values, indicating that these populations were responsible for most of the observed $\mathrm{G} \times \mathrm{E}$ interaction.

These findings have implications for selection, but they will help culling the worst populations rather than selecting the best ones. The population from Miechów (21) showed the poorest growth. That seed orchard represents Scots pine from high altitudes, thus adapted to harsh environmental conditions. Similarly, the poor performance of other two populations from the southeastern Poland [Józefów (14) and Janów Lubelski (38)], and only average at most performance of other populations from that region (Świdnik (25), Sieniawa (31) and Leżajsk (33)—all genetically related to Józefów), indicate that use of seeds from these populations should be avoided, and these seed orchards should be used as gene banks only. A stably poor performance of population Runowo 1 (10) is surprising, given that other related populations [Runowo 2-4 (11-13), Gniewkowo (2)] showed better, although close to average, growth. This seed orchard had the fewest (31) clones within this group of related populations. Thus, its poor performance may reflect the effect of clone number and thus genetic diversity on progeny fitness.

Existence of $\mathrm{G} \times \mathrm{E}$ interaction has important implications for selection also in terms of the usefulness of test sites as selection environment. Large differences among sites (see above) and the variable performance of populations across sites suggest that our test locations should not be treated uniformly regarding to selection. We suggest that sites at Kórnik and Choczewo should be assigned to one group, Wymiarki and Janów Lubelski to the other, and the Gołdap site should be considered separately. The Kórnik and Choczewo sites are perhaps the best locations to select at, because they provide the greatest site quality, and population differences are best expressed there (White et al. 2007). Likely, the edaphic factor is predominant in this site distinction because those two sites were established on more fertile abandoned agricultural lands (Chmura et al. 2003); however, some climatic influences could not be excluded. Validity and generality of proposed site division should be further tested based on population productivity and detailed climatic and edaphic data.

Phenology, growth rhythm and needle traits

Examined populations varied significantly in spring growth phenology. Large variation among populations in time to bud burst is usually noted in studies involving large geographic transfers of planting material (e.g. Oleksyn et al. 2001; Rehfeldt 1978). Adaptation of growth rhythm to environmental conditions is often critical for survival and 
growth in forest trees. Observations of bud burst in our study were correlated well across sites and years, indicating that differences in spring phenology were genetically based, and the relative differences among populations were stable. We found a tendency of populations that originated from the sites of harsher climate in Poland to burst their buds early (see Fig. 3) compared to those originated from milder climates. Such a geographic pattern of variation in bud burst agrees well with the findings with more broadly distributed seed sources of Scots pine (reviewed in Giertych 1991). Interestingly, whereas one of the high-altitude populations in our study [Międzylesie (4)] was early budbursting, the other [Miechów (21)] fell into a group of late bud-bursting ones. The seed orchard in Miechów was established at a lower altitude than the origin of its clones. Consequently, such a result may reflect the maternal aftereffects similar to those observed in Norway spruce (Johnsen 1988; Johnsen and Skrøppa 1996; Skrøppa et al. 2007). A possible genetic relatedness among progenies of some seed orchards in our study finds a reflection in the results of bud burst phenology, but fit well within a general pattern of variation in this trait (see "Methods" section and Fig. 3).

Although phenological observations in our dataset were in general correlated, there was a weak correlation between bud burst observations and the estimates of bud burst derived from the growth curves at the Kórnik site (START DAY) in 2002. This was caused by three outlier populations that were late bud-bursting based on observations, but early bud-bursting based on START DAY. The likely reason for that apparent contradiction lays in the nature of the START DAY, which reflects not only phenology, but also growth rate and the final leader length (see also Table 3). Overall, a positive correlation between bud burst phase and tree growth indicates that populations with relatively earlier bud burst showed stronger growth than late bud-bursting ones. The link between growth and phenology would be perhaps best explained in terms of volume production per unit area as an integration of tree growth and survival. However, we did not investigate volume growth, but assuming the tree height and diameter are good indicators of productivity, and given no significant negative relationship between bud phenology and survival, we conclude that early bud-bursting had no negative consequences for the investigated progenies of Scots pine. Testing bud burst data against relevant climatic indices (e.g. degree-days, mean annual temperatures at the origin site, number of frost-free days, etc.) to examine predictive power of climate-phenology relationships that would help better resolve population variation in our dataset is warranted.

The analysis of growth rhythm revealed a strong negative correlation between shoot elongation time and START DAY in 2002. Shoot elongation time in trees is usually more strongly and positively correlated with the end of a growing season than with the beginning (Chmura 2006; Skrøppa and Magnussen 1993; Ununger et al. 1988; von Wuehlisch and Muhs 1991). Therefore, our finding from 2002 was unexpected, but not unusual; Ununger et al. (1988) found similar correlation for Norway spruce in one out of five examined growing seasons. However, the 2003 growth rhythm in our study likely represents more typical result in line with other studies in conifers.

Variation in growth rate and shoot elongation time have been found in forest trees provenance experiments involving wide geographic transfers (Oleksyn et al. 2001; Rehfeldt 1986a, b; Skrøppa and Magnussen 1993). This variation is often related to climatic conditions at the site of origin. In Scots pine, for example, RGR was found to covary with mean annual temperature at the origin site, and variation in height growth among distinct groups of populations resulted from variation in both growth rate and shoot elongation time (Oleksyn et al. 2001). In our study, the examined populations varied significantly in leader elongation time and the relative growth rate, but we did not find any clear geographic pattern in these traits. Moreover, even accounting for variation in RGR and shoot elongation time, the large part of variation in leader length remained unexplained.

Differences among populations in plant or tissue nitrogen concentrations may reflect differences in the uptake and accumulation or nutrient-use efficiency. Significant variation among populations in provenance experiments was found in jack pine for seedling $\mathrm{N}$ concentration (Giertych and Farrar 1962; Mergen and Worrall 1965) and in Scots pine for needle N (Gerhold 1959; Reich et al. 1996). These findings indicate that $\mathrm{N}$ concentration generally increases with increasing climatic harshness at the site of origin. We found differences in needle $\mathrm{N}$ concentrations among our populations, but no clear association between needle $\mathrm{N}$ on mass basis and tree growth. Moreover, there was no variation in time trend of foliar $\mathrm{N}$ or other leaf traits either among populations within the subset or among predefined groups of populations. Nitrogen dynamics in newly developed needles in our experiment is consistent with the annual $\mathrm{N}$ dynamics observed for Scots pine in other studies (Helmisaari 1990; Oleksyn et al. 2002). An initial decrease in mass-based $\mathrm{N}$ likely resulted from needle growth and dilution effect, because area-based $\mathrm{N}$ continued to increase in those needles throughout the sampling period. A discrepancy between mass and areabased needle $\mathrm{N}$ is explained by a decreasing time trend in SLA that may serve as a conversion factor (area-based $\mathrm{N}=$ mass-based N/SLA). In our study, the SLA and needle $\mathrm{N}$ on area basis showed significant correlations with tree height, but not with leader length or RGR. These findings suggest that there is no direct link between leaf morphology or chemistry and tree height growth. These 
attributes must be included in more detailed studies that integrate aspects of morphology and physiology with tree growth. From a practical point of view, we conclude that the observed variation in growth rhythm and its components was too small to support selection decisions.

\section{Role of the funding source}

Preparation of the manuscript was partially funded by the Polish State Forests, the Institute of Dendrology (IDPAN) and the Fulbright scholarship to DJC. These institutions facilitated collection of the data and preparation of the manuscript, but had no involvement in data interpretation and the decision to submit the paper for publication.

Acknowledgments We acknowledge funding for this study from the Polish State Forests, the Institute of Dendrology (IDPAN), and the Fulbright scholarship. We thank Prof. M. Giertych for the initiation of this experimental series and the Polish State Forests for the maintenance of experimental sites. DJC thanks Dr. Mark G. Tjoelker for hosting at Texas A\&M University. Tim Rogers helped with elemental analyses. We highly appreciate the field and laboratory assistance from Dr. M.Guzicka, H. Przybył and M. Andrejew. Comments by two anonymous Reviewers helped to improve early version of the manuscript.

Conflict of interest The authors declare no actual or potential conflict of interest.

Open Access This article is distributed under the terms of the Creative Commons Attribution License which permits any use, distribution, and reproduction in any medium, provided the original author(s) and the source are credited.

\section{References}

Baker FS (1950) Principles of silviculture. McGraw-Hill, New York, NY, USA

Becker HC (1981) Correlations among some statistical measures of phenotypic stability. Euphytica 30(3):835-840

Becker HC, Léon J (1988) Stability analysis in plant breeding. Plant Breed 101(1):1-23

Beuker E (1994) Adaptation to climatic changes of the timing of bud burst in populations of Pinus sylvestris L. and Picea abies (L.) Karst. Tree Physiol 14(7-9):961-970

Bonnet-Masimbert M, Webber JE (1995) From flower induction to seed production in forest tree orchards. Tree Physiol 15(7-8): $419-426$

Burczyk J, Giertych M (1991) Response of Norway Spruce (Picea abies [L.] Karst) annual increments to drought for various provenances and locations. Silvae Genet 40(3-4):146-152

Causton DR, Elias CO, Hadley P (1978) Biometrical studies of plant growth. I. The Richards function, and its application in analysing the effects of temperature on leaf growth. Plant Cell Environ 1(3): 163-184

Chałupka W (1991) Usefulness of hormonal stimulation in the production of genetically improved seeds. Silva Fenn 25(4):235-240
Chmura DJ (2006) Phenology differs among Norway spruce populations in relation to local variation in altitude of maternal stands in the Beskidy Mountains. New For 32:21-31

Chmura DJ, Giertych M, Rożkowski R (2003) Early height growth of Scots pine (Pinus sylvestris L.) progenies from Polish clonal seed orchards. Dendrobiology 49:15-23

Cornelissen JHC, Castro-Diez P, Carnelli AL (1998) Variation in relative growth rate among woody species. In: Lambers $\mathrm{H}$, Poorter H, Van Vuuren MMI (eds) Inherent variation in plant growth. Physiological mechanisms and ecological consequences. Backhuys, Leiden, pp 363-392

Eberhart SA, Russell WA (1966) Stability parameters for comparing varieties. Crop Sci 6:36-40

Evans JR (1998) Photosynthetic characteristics of fast- and slowgrowing species. In: Lambers $\mathrm{H}$, Poorter H, Van Vuuren MMI (eds) Inherent variation in plant growth. Physiological mechanisms and ecological consequences. Backhuys, Leiden, pp 101-119

Everitt B (1980) Cluster analysis. Halsted Press, New York

Finlay KW, Wilkinson GN (1963) The analysis of adaptation in a plant-breeding programme. Aust J Agr Res 14:742-754

Gerhold HD (1959) Seasonal variation of chloroplast pigments and nutrient elements in the needles of geographic races of Scotch pine. Silvae Genet 8(4):113-123

Giertych M (1991) Provenance variation in growth and phenology. In: Giertych M, Matyas C (eds) Genetics of Scots pine. Elsevier, Amsterdam, pp 87-101

Giertych M (1999) The impact of selection practices on the biological diversity of production forests in Poland. In: Rykowski K, Matuszewski G, Lenart E (eds) Evaluation of the impact of forest management practices on biological diversity in central Europe. A case study on Polish Forest Act and other regulations. Forest Research Institute, Warsaw, pp 59-78

Giertych MM, Farrar JL (1962) A provenance study of jack pine seedlings. Silvae Genet 11(4):111-114

Helmisaari HS (1990) Temporal variation in nutrient concentrations of Pinus sylvestris needles. Scand J For Res 5:177-193

Hunt R (1982) Plant growth curves. The functional approach to plant growth analysis. Edward Arnold, London

Isik K, Kleinschmit J (2003) Stability-related parameters and their evaluation in a 17-year old Norway spruce clonal test series. Silvae Genet 52(3-4):133-139

Johnsen $\emptyset$ (1988) After-effects on progenies from orchard clones moved to non-native environments. In: Worrall J, Loo-Dinkins J, Lester DP (eds) Proceedings of the tenth North American forest biology workshop, July 20-22, 1988. Vancouver, BC, Canada, pp 1-11

Johnsen $\varnothing$, Skrøppa T (1996) Adaptive properties of Picea abies progenies are influenced by environmental signals during sexual reproduction. Euphytica 92(1-2):67-71

Li B, McKeand SE (1989) Stability of loblolly pine families in the Southeastern United States. Silvae Genet 38(3-4):96-101

Matheson AC, Cotterill PP (1990) Utility of genotype x environment interactions. For Ecol Manag 30(1-4):159-174

Mátyás C (1981) Kelet-európai erdeifenyő-származások fenológiai változékonyasága (Phenologic variability of east European Scots pine provenances). Erdészeti Kutatások 74:71-80

McKeand S, Mullin T, Byram T, White T (2003) Deployment of genetically improved loblolly and slash pines in the south. J For 101(3):32-37

Mergen F, Worrall J (1965) Effect of environment and seed source on mineral content of jack pine seedlings. For Sci 11:393-400

Mikola J (1991) Unilization of improved material: a survey. In: Giertych M, Matyas C (eds) Genetics of Scots pine. Elsevier, Amsterdam, pp 265-275

Morgenstern EK (1982) Interactions between genotype, site and silvicultural treatment. Information Report PI-X-14. Petawawa 
National Forestry Institute, Canadian Forestry Service, Department of the Environment

Morgenstern EK, Teich AH (1969) Phenotypic stability of height growth of Jack pine provenances. Can J Genet Cytol 11(1): $110-117$

Oleksyn J, Reich PB, Tjoelker MG, Chalupka W (2001) Biogeographic differences in shoot elongation pattern among European Scots pine populations. For Ecol Manag 148(1-3):207-220

Oleksyn J, Reich PB, Zytkowiak R, Karolewski P, Tjoelker MG (2002) Needle nutrients in geographically diverse Pinus sylvestris L. populations. Ann For Sci 59(1):1-18

Owino F (1977) Genotype x environment interaction and genotypic stability in loblolly pine. II Genotypic stability comparisons. Silvae Genet 26(1):21-26

Poorter H (1989a) Interspecific variation in relative growth rate: on ecological causes and physiological consequences. In: Lambers H, Cambridge ML, Konings H, Pons TL (eds) Causes and consequences of variation in growth rate and productivity of higher plants. SPB Academic Publishing, The Hague, pp 45-68

Poorter H (1989b) Plant growth analysis: towards a synthesis of the classical and the functional approach. Physiol Plant 75(2): 237-244

Poorter H, Garnier E (1996) Plant growth analysis: an evaluation of experimental design and computational methods. J Exp Bot 47(302):1343-1351

Poorter H, Garnier E (1999) Ecological significance of inherent variation in relative growth rate and its components. In: Pugnaire FI, Valladares F (eds) Handbook of functional plant ecology. Marcel Dekker, New York, pp 81-120

Poorter H, Niinemets U, Poorter L, Wright IJ, Villar R (2009) Causes and consequences of variation in leaf mass per area (LMA): a meta-analysis. New Phytol 182(3):565-588

Prescher F (1982) Testning av tilväxtrytm och tillväxtförmåga för bruksprovenienser av gran (Growth rhythm and growth ability in Norway spruce provenances), Report No. 10. The Swedish University of Agricultural Sciences, Department of Forest Yield Research

Rehfeldt GE (1978) Genetic differentiation of Douglas-fir populations from the northern Rocky Mountains. Ecology 59(6):1264-1270

Rehfeldt GE (1982) Differentiation of Larix occidentalis populations from the northern Rocky Mountains. Silvae Genet 31(1):13-19

Rehfeldt GE (1986a) Adaptive variation in Pinus ponderosa from intermountain regions. I. Snake and Salmon River Basins. For Sci 32(1):79-92

Rehfeldt GE (1986b) Adaptive variation in Pinus ponderosa from intermountain regions. II. Middle Columbia River system. Research Paper INT-737. USDA Forest Service, Intermountain Research Station

Reich PB, Oleksyn J, Tjoelker MG (1996) Needle respiration and nitrogen concentration in Scots pine populations from a broad latitudinal range: a common garden test with field-grown trees. Funct Ecol 10(6):768-776

Reich PB, Ellsworth DS, Walters MB (1998a) Leaf structure (specific leaf area) modulates photosynthesis-nitrogen relations: evidence from within and across species and functional groups. Funct Ecol 12(6):948-958

Reich PB, Walters MB, Tjoelker MG, Vanderklein D, Buschena C (1998b) Photosynthesis and respiration rates depend on leaf and root morphology and nitrogen concentration in nine boreal tree species differing in relative growth rate. Funct Ecol 12(3): 395-405

Richards FJ (1959) A flexible growth function for empirical use. J Exp Bot 10(29):290-300

Shutyaev AM, Giertych M (1997) Height growth variation in a comprehensive Eurasian provenance experiment of (Pinus sylvestris L.). Silvae Genet 46(6):332-349

Shutyaev AM, Giertych M (2000) Genetic subdivisions of the range of Scots pine (Pinus sylvestris L.) based on a transcontinental provenance experiment. Silvae Genet 49(3):137-151

Skrøppa T, Magnussen S (1993) Provenance variation in shoot growth components of Norway spruce. Silvae Genet 42(2-3):111-120

Skrøppa T, Kohmann K, Johnsen Ø, Steffenrem A, Edvardsen ØM (2007) Field performance and early test results of offspring from two Norway spruce seed orchards containing clones transferred to warmer climates. Can J For Res 37(3):515-522

St. Clair JB, Kleinschmit J (1986) Genotype-environment interaction and stability in ten-year height growth of Norway spruce clones (Picea abies Karst.). Silvae Genet 35(5-6):177-186

St. Clair JB, Mandel NL, Vance-Boland KW (2005) Genecology of Douglas fir in western Oregon and Washington. Ann Bot 96(7): 1199-1214

Steiner KC (1979a) Patterns of variation in bud-burst timing among populations in several Pinus species. Silvae Genet 28(5-6): $185-194$

Steiner KC (1979b) Variation in bud-burst timing among populations of interior Douglas-fir. Silvae Genet 28(2-3):76-79

Ununger J, Ekberg I, Kang H (1988) Casual relationship between juvenile shoot growth characters in Picea abies. Scand J For Res 3:147-156

von Wuehlisch G, Muhs HJ (1991) Environmental influences on juvenile shoot growth in Picea abies. Scand J For Res 6:479-498

von Wuehlisch G, Krusche D, Muhs HJ (1995) Variation in temperature sum requirement for flushing of beech provenances. Silvae Genet 44(5-6):343-346

White TL, Adams WT, Neale DB (2007) Forest genetics. CABI Publishing, Cambridge, MA, USA

Wricke G (1962) Über eine Methode zur Erfassung der ökologischen Streubreite in Feldversuchen. Z Pflanzenzücht 47(1):92-96

Wright IJ et al (2004) The worldwide leaf economics spectrum. Nature 428(6985):821-827

Yeiser JL, Lowe W, Van Buijtenen JP (2001) Stability and seed movement for loblolly pine in the Western Gulf Region. Silvae Genet 50(2):81-88

Załęski A, Zajączkowska B, Matras J, Sabor J (2000) Leśna regionalizacja dla nasion i sadzonek w Polsce. Centrum Informacyjne Lasów Państwowych, Warszawa

Zobel B, Talbert J (1984) Applied forest tree improvement. Wiley, New York, USA 